\title{
Impact of Covid-19 pandemic on Gayo coffee agroindustry
}

\author{
Rachman Jaya ${ }^{1}{ }^{*}$, Rizki Ardiansyah ${ }^{1}$, Cut Hilda Rahmi $^{1}$, and Yusriana ${ }^{2}$ \\ ${ }^{1}$ Assessment Institute for Agricultural Technology of Aceh, 23125 Banda Aceh, Indonesia \\ ${ }^{2}$ University of Syiah Kuala, Agricultural Post Harvest Technology Department, 23111 Banda Aceh, \\ Indonesia
}

\begin{abstract}
The objective of this paper is to assess the impact Covid19 pandemic on the agro-industry of Gayo coffee. The research was undertaken by a survey on activities business of Gayo coffee which involves market system after the harvest season, as a comparison is used business condition before Covid19 pandemic. The study was conducted on several agro-industry based on small and medium industries using structured-questioner in Bener Meriah and Aceh Tengah district, Gayo highland. An overview before pandemic describes that the price of Gayo cherry about IDR. $10.000-14.000 / \mathrm{kg}$ and the price of green bean export quality IDR. $60.000-80.000 / \mathrm{kg}$. On the other hand, both prices during pandemic IDR.6.000-8.000/kg and IDR. 35.000-45.000/kg.Until July 2021, the Covid19 pandemic is not yet finished, whereasmainly the activities in the agro-industry at Gayo were stopped (temporary) due to lockdown policy by the national and local governments. This condition has influenced on economic growth of the Gayo highland and actors who is included in Gayo coffee agroindustry.
\end{abstract}

\section{Introduction}

Gayo highland is a part of the Bukit Barisan Mountain, which is located in Aceh Province (figure 1). This area consists of 3 districts, such as Bener Meriah, Central Aceh, and Gayo Lues. The altitude of this area is about 600-1600 m above sea level that suitable for Arabica coffee. For a long time ago, Arabica coffee from Gayo has been known to the world, due to excellent quality and in terminology, coffee called specialty coffee. For Gayo communities, coffee has provided $90 \%$ of their livelihoods, in another word this commodity is the main source of the regional economy. However, nowadays the current income of the Gayo farmers is declining due to the low productivity of coffee which is about $600-754 \mathrm{~kg} / \mathrm{ha}[1-$ $2],[13]$. This is caused by pests and disease, mostly unproductive plants ( $>20$ years) as well as not implementing the Good Agriculture Practices (GAP). Before the Covid19 pandemic, the demand for Gayo coffee has been an increase, especially from major cities of Indonesia, such as Jakarta, Bandung, Medan, and Banda Aceh. Production Gayo arabicacoffee in 2017 reaches 68.500 tons with a value of 200 million US dollars. There are gaps between the low of productivity and high demand for Gayo arabica coffee $[1,2]$.

* Corresponding author: jaya.rachman@yahoo.co.id 
At the end of December 2019, the world shocked by pandemic Covid19 occurred in China, especially in Wuhan, Hubei Province. The pandemic has spread throughout the world in no more than 1years including Indonesia, which was begun from in Jakarta. Until May 13 there were 1.85 million cases, recovery 1.691 million, and 51.095 deaths [9]. According to [5] before the Covid19 pandemic, mankind has shocked by several viruses such as Ebola, Mers, H1N1, Sars, and H7N1 even Aids. Furthermore the pandemic involvement of the livelihood of 7.7 billion in 211 countries and more than 250.000 deaths by estimated including in Africa [6], whereas in Europe majority confirmed Covid19 at Italy, German, Spain [7], USA, South America and Asia [8].

To control this condition, several governments have been policy to cut-off a pandemic such as a lockdown, likewise the Indonesia government and local government, therefore the policies made are social distancing by zones. Critically of this condition was implication will occur caused mainly the production activities are stopped. In this article, we discuss the impact of the policy on business Gayo coffee by agroindustry. Based on an overview, the research gap discusses what is the impact occurred by the Covid19 pandemic on Gayo coffee agroindustry? The objective of this paper was to obtain an impact of the lockdown or PSBB policy involves technical and social aspects. In this paper, we only limit qualitative data of impact lockdown/PSBB policy.

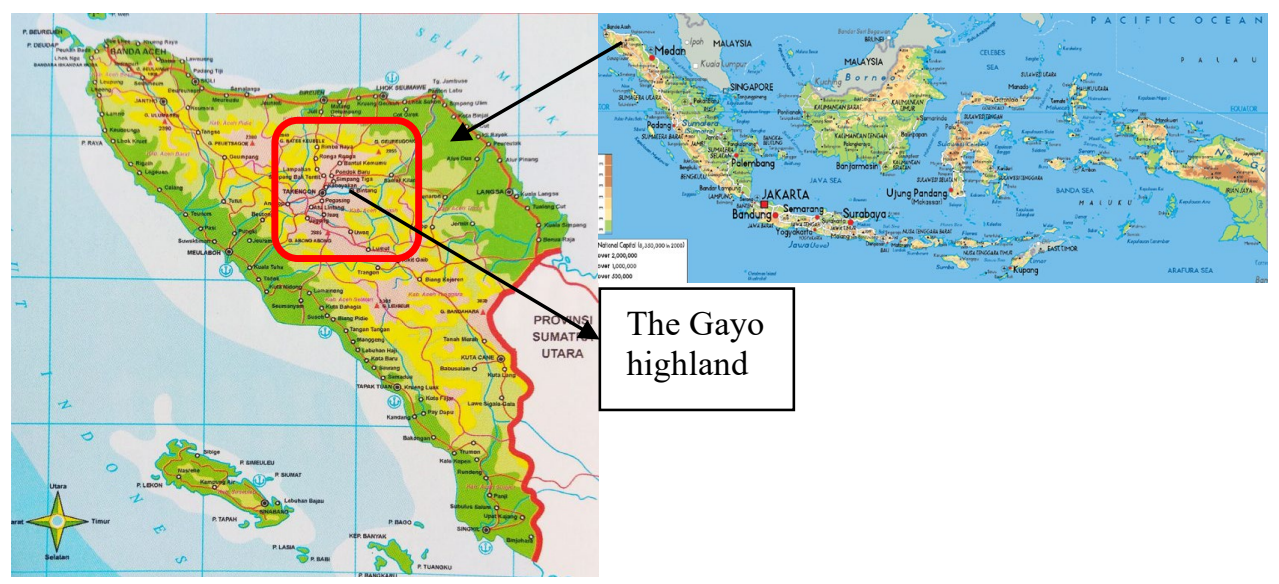

Fig. 1. The map of Aceh Province, Indonesia and the Gayo highland location.

\section{Methodology}

\subsection{Logical Framework}

The framework of this research was a hardly condition for all actors who involves in the business system of Gayo coffee, especially the farmer, middle man and small agro-industry. The condition was basically due to the Covid19 pandemic and the policy of social distancing by zone. Results of the first observation team show that nowadays, after 2 harvesting season (2019 September-2020 March and 2020 September-March 2021) almost not bought by market, including regional, national, and export. This occurs due to applying lockdown or PSBB policy by the national and local governments. Expect, several agroindustries or koperasi that have a contract selling with the buyer. Based on this fact, it's very important to assess the impact of the Covid19 pandemic on business and social aspects as well as critically a lesson learned to arrange the same conditions for the future. 


\subsection{Research design}

The research activities have begun in Februarys 2020, after a pandemic hit in Indonesia, including Gayo highland areas, Aceh Province. Research undertook at Gayo on Bener Meriah and Aceh Tengah districts, justification of its both of district were central production of Gayo coffee. The data were collected primer and secondary. Primer data involved through observation on several agro-industrial which was grouped small and medium scale. The information was collected involve numbers of employees, middle-man and farmers members, production capacity, purchase price by middle-man and farmers, warehouse capacity, and general condition during the Covid19 pandemic. The determinations numbers of samples by purposive sampling [4], numbers of agro-industrial were 2 for medium scale and 4 for small scale at Aceh Tengah and Bener Meriah district.

In the study, we used a semi-structured questioner to survey and collect data as well as to interview several key informants such as farmers, middle man, and agroindustry. Data were analyzed by qualitative-analytic [3] which focused on an impact technical and social aspect. The technical impact refers to the condition of Gayo coffee which was absorbed by market and effort of agro-industry to conduct this problem. The social impact related to occur situation on farmers, middle-man, and agro-industry after all activities have stopped during Covid19 pandemic and lockdown/PSBB policy was activated by government and local government.

\section{Result and discussion}

\subsection{Business Gayo coffee before covid-19 pandemic}

Gayo coffee is one of the most coffees preferred in the world namely specialty coffee, beside Toraja from South Sulawesi, Kintamani (Bali), Wamena (Papua), Mandheling (North Sumatera), Kadatuan (West Java), Blue Mountain from Jamaica, and Sidama from South Ethiopia [2, 10, 11, 20]. Gayo coffee is generally prepared by wet processing methods. Gayo coffee has a strong aroma and balance body [18]. Gayo coffee is an economic force driving for Aceh Province, especially Gayo Highland [12] totally, value trade of its reach $\$ 40$ million in 2016. Several majority importer countries of Gayo coffee are USA, Japan, German, Italy, Russia, Malaysia, China, and Australia [13]. In system production of Gayo coffee, many actors and activities involved, it's described on figure 2 as follow:

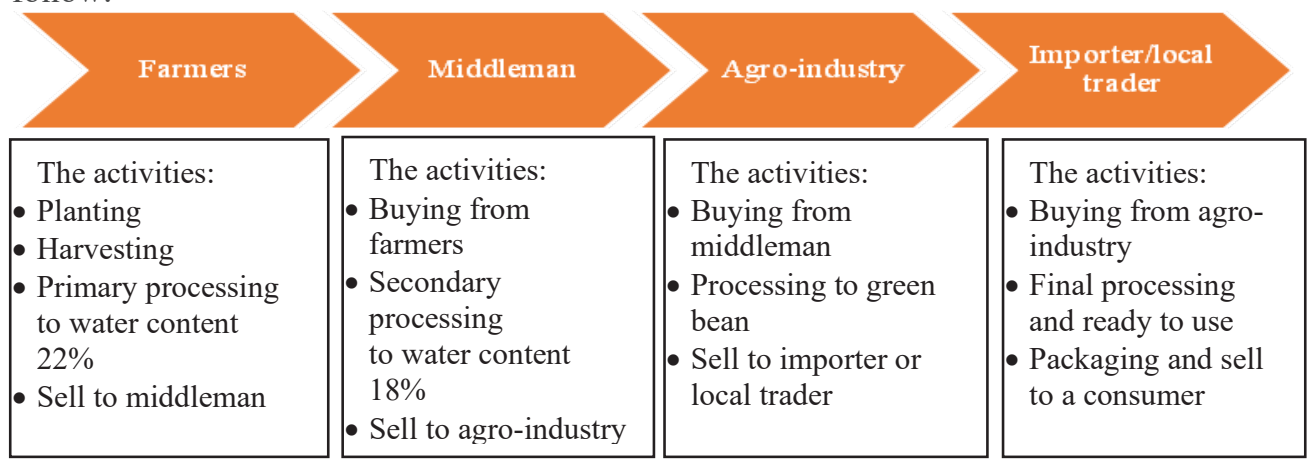

Fig. 2. The system production of Gayo coffee 
Based on the demography, according to [14] a total of households who are involved in the Gayo coffee production system are 103.434, with a planting area of 123.000 ha. Since 2012-2018 (figure 3) has increased production $26.10 \%$, where the total production of Gayo coffee in 2018 reaches 68.493 tons, an increase of about 14.179 tons compared to 2012 . Around $80 \%$ of Gayo people hanging their lives on coffee Gayo, including many actors besides farmers such as agro-industries, coffee shops, roasting services, warehouse services, and transportation. Related to agro-industry, generally, market system to exports was undertaken by contract with buyers, furthermore, more than 95\% market-share of Gayo coffee is exported to many countries such as USA, Europe-union, Japan, South Korea, New Zealand, Finland, Malaysia and Australia. On the other hand, for the national, regional and local markets, normally the business is completed by cash and carry system. To increase the value-added of Gayo coffee has been implemented several certifications which the point was to protect Gayo coffee by fraud market system and ensure sustainable production. Its likes Utz Certified, Indication Geographies (IG), Organic certifications (JAS, EU, USDA/NOP, SNI), GAP, HACCP, Rain-forest Alliance, Fair-trade, and 4C [15], [16], [18],[19]. According to [19] each of those certifications has different purposes. Based on the description, we can see that Gayo coffee is very important for Gayo people. The next section will be discussed an impact that occurred after the lockdown/PSBB policy is implemented during the Covid19 pandemic.

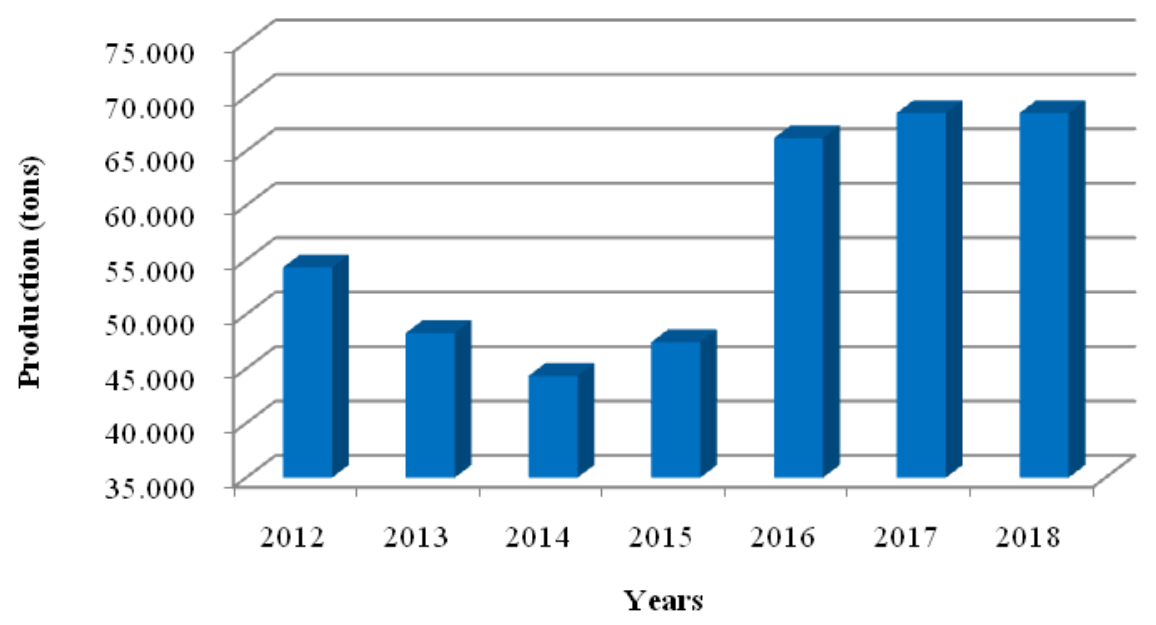

Fig. 3. Production of Gayo coffee since 2012-2018

\subsection{Business Gayo coffee during Covid19 pandemic}

Our focuses in this research were to describe of Gayo coffee business condition during the Covid19 pandemic and propose a solution that can be adopted by a stakeholder to help actors who contributed to the business, especially farmers, middlemen and small agroindustry. Related to farmers, after harvesting season, they have to prepare for next season soon and so has a lot of money for it. Nowadays, Gayo coffee owned by farmers (figure 4) wasn't bought by middle-man, this condition also occurs in the agro-industry due to purchase contract with the buyer (importer) and the local trader has been stopped. This condition is a consequence (force-majeure) of the lockdown/PSBB policy of both countries. Globally, during Covid19 pandemic has been reduction coffee demand of $0.95 \%$ or 1.6 million $60 \mathrm{~kg}$ bag. The reduction related to the impact of social distancing on out of home 
consumption as large parts of the hospitality industry are under lockdown and workplace closed [21].
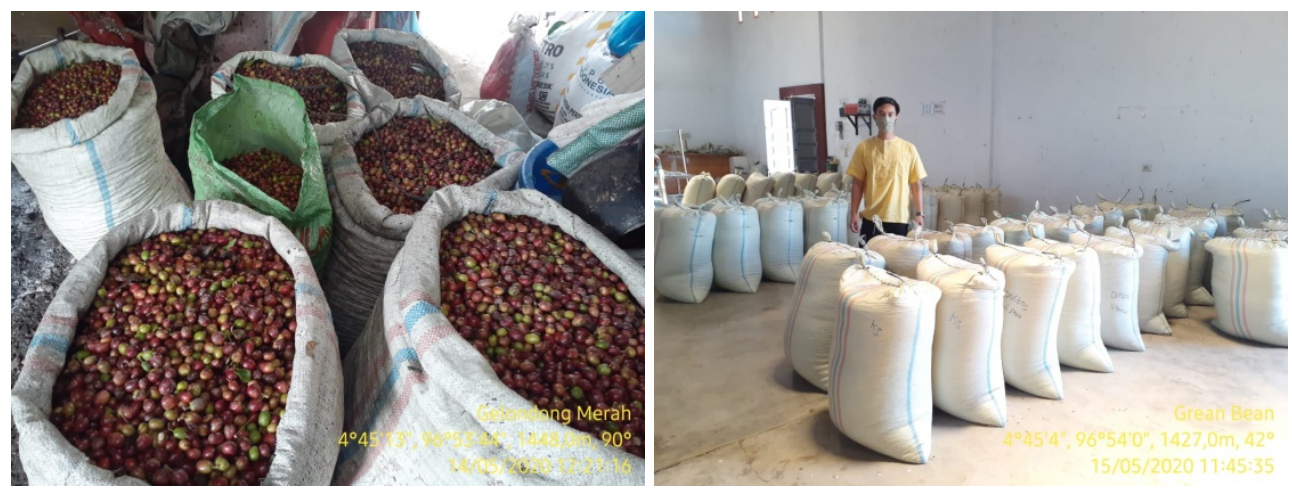

Fig. 4. Gayo coffee piled-up at farmers and agro-industry warehouse

Based on describes before the paragraphs, what should be done by the national, province particularly local government to take this condition. The most urgent is giving bailout to agro-industry or implanted warehouse receipt system (WRS). According to [17] this system is suitable to overcome the situation. The question is, what the local government has a sufficient foundation to buy all the coffee, especially on farmers caused the coffee still cherry. On the other side, furthermore [17] stated that implementation of WRS in Gayo highland was limited (Table 1). Several reasons explain it's as follows: 1) An administration is very complicated, 2) The storage services fee is $6 \% /$ years from the value of the transaction, 3) Storage period for 5 months only, 4) The warehouse facility does not technically qualify, and 5) The risk fee by bank guarantee is up to $30 \%$.

Table 1. Implementation of WRS and comparison of total production and participated

\begin{tabular}{ccccccc}
\hline & \multicolumn{3}{c}{ Transaction } & Financing & & $\begin{array}{c}\text { Total } \\
\text { years }\end{array}$ \\
\cline { 2 - 5 } & $\begin{array}{l}\text { Numbers of } \\
\text { receipt } \\
\text { (sheet) }\end{array}$ & $\begin{array}{l}\text { Volume } \\
\text { (tons) }\end{array}$ & $\begin{array}{l}\text { Value } \\
\text { (IDR/billion) }\end{array}$ & $\begin{array}{c}\text { Value } \\
\text { (IDR/billion) }\end{array}$ & $\begin{array}{c}\text { Percentage } \\
\text { of participant } \\
\text { in WRS }\end{array}$ \\
\hline 2014 & 1 & 5 & 0.2 & - & 44.343 & 0.01 \\
2015 & 13 & 440 & 26 & 15.4 & 47.444 & 0.92 \\
2016 & 2 & 50 & 3 & 2.1 & 66.200 & 0.07 \\
2017 & 6 & 90 & 5.8 & 3.8 & 68.500 & 0.13 \\
2018 & 4 & 40 & 3.6 & 2.5 & 68.493 & 0.06 \\
Total & 24 & 625 & 38.6 & 23.8 & & \\
\hline
\end{tabular}

Sources: $[14,17]$

In this research, during the Covid19 pandemic the main problem on Gayo coffee commodity is the green bean of its have not been sold. This fact occurred during the pandemic due to declining demand by the importer and regional trader. Especially on the importer, there was postponement shipping with several problems such as hard to get a space on the ship and average the warehouse at importer countries has full. The same case also occurred in the regional and national markets. The problem of Gayo ethnic got worse on the next major harvest, to solve this problem. One of the ways this is applying the WRS system. But there are lacks of the system, at least an instrument that is relevant to help the Gayo ethnic. Although, with some improvements. Especially the farmers who are needed a lot of costs to prepare for the next planting season. 
Besides being based on the WRS system, one of the solutions that can be applied is increasing the national market, specifically on several cities that has prospective growth, but it has no resources Arabica coffee such as main cities in Kalimantan Island: Banjarmasin, Balikpapan, Samarinda, Pontianak, Palangkaraya. If international trade is hampered by availability of ship due to decline the trading between countries, then the opposite with the national trade (inter-island trade).

\section{Conclusion and recommendation}

\subsection{Conclusion}

Before the Covid19 pandemic and implementation of a lockdown and social distancing policy by national, provincial and local government, Gayo coffee is the main commodity for the livelihood of Gayo people. But, during the Covid19 pandemic and after the policy is implemented, all business activities have been stopped (temporary). This condition has implication for the Gayo highland economy and certainly on social dimension. There are several solutions that can be implemented by the local government to overcome the problem such as immediately provide to bailout coffee cherries from farmers, middle-man as well as agro-industry.

\subsection{Recommendation}

The schema that can be implemented is the WRS system to the control of Covid19 pandemic such as, therefore the systems have to improve to take our problems on the field. Technically is needed equity capital by issuing a regent/province regulation which is approved by the local House of Representatives. On the other hand, short-term solution that can be applied by national or local government is developing national market such as on several cities in Kalimantan Island which has no resources Arabica coffee such as Banjarmasin, Balikpapan, Samarinda and Pontianak, whereas coffee-shops growth also high caused by life style changing, mostly on the millennial generation.

\section{References}

1. R. Jaya, Machfud, S. Raharja, Marimin, J. Teknologi Industri Pertanian 24, 1 (2014)

2. R. Jaya, M. Ferizal, R. Ardiansyah, Husaini, I. Mirza, Ishar, Asis, M. Ismail, F.F.F. Rahmah, Yusriana, Sustainability design for development of Gayo's Science Park's, IOP Conf. Ser. Earth Environ. Sci. 418 (2019)

3. U. Flick, Mapping the field handbooks of qualitative data analysis (Sage, Washington, 2013)

4. R. Hendayana, Analisis data pengkajian (IAARD Press, Jakarta, 2016).

5. P.K. Law, Open Journal of Regenerative Medicine 9, (2020)

6. A.A. Anjorin, Asian Pacific Journal of Tropical Medicine 13, (2020)

7. ENDC, Coronavirus disease 2019 (COVID-19) pandemic: increased transmission in the EU/EEA and the UK - seventh update (ENDC, Stockholm, 2020)

8. F. Di Gennaro, D. Pizzol, C. Marotta, M. Antunes, V. Racalbuto, N. Veronese, L. Smith Int. J. Environ. Res. Public Health 17, (2020)

9. Gugus tugas penanganan Covid19 2021 Peta sebaran kasus positif Covid19 download June 42021 https://covid19.go.id.

10. F.T. Tadesse, Y. Jemal, H. Abebe, 2015 J. Nutr. Ecol. Food Res. 3, 1 (2015) 
11. J. Daly, D. Hamrick, P. Bamber, K. Fernandez-Stark, Jamaica in the arabica coffee global value chain (Duke University, Duke, 2018)

12. Mariyudi, Suryadi, M. Sayuti, H. Raza, Indian J. of Public Health Research \& Development 9, 12 (2018)

13. Badan Pusat Statistik, Indonesian coffee statistic (BPS Press, Jakarta, 2017)

14. Badan Pusat Statistik, Aceh province in figure (BPS Aceh Press, Banda Aceh, 2019)

15. T. Damayanti, H. Setiadi, The Influence of certificaton of Gayo coffee geographical indication against value added of coffee in Gayo Highlands, Aceh IOP Conf. Ser. Earth and Environ. Sci. 338 (2019)

16. K.A. Lochner, Kopi, koperasi and fair-trade: perspectives from the Gayo Highlands of Indonesia (thesis degree) (University of Sidney, Sidney, 2018)

17. K. Fadhiela, D. Rachmina, R. Winandi, Jurnal Agribisnis Indonesia 6, 1 (2018)

18. T. Wahyudi, M. Jati, Challenges of sustainable coffee certification in Indonesia ICO conference, in Proceeding International Conference the Ecology Social and Environmental on Impact of Certification on the Coffee Supply Chain, 25 September 2012, London, England (2012)

19. M. Ibnu, A. Offermans, P. Glasbergen, Bulletin of Indonesian Economic Studies 54, 3 (2018)

20. J.F. Rahman, D.M. Rahmah, Jurnal Teknologi dan Manajamen Agroindustri 7, 3 (2018) 